\title{
UCRL-TR-200331
}

LAWRENCE LIVERMORE NATIONAL LABORATORY
Data Summary for the Pre Survey Interim Status Closure of the Area 514 Facility

Anthony Be Lue

October 13, 2003 
This document was prepared as an account of work sponsored by an agency of the United States Government. Neither the United States Government nor the University of California nor any of their employees, makes any warranty, express or implied, or assumes any legal liability or responsibility for the accuracy, completeness, or usefulness of any information, apparatus, product, or process disclosed, or represents that its use would not infringe privately owned rights. Reference herein to any specific commercial product, process, or service by trade name, trademark, manufacturer, or otherwise, does not necessarily constitute or imply its endorsement, recommendation, or favoring by the United States Government or the University of California. The views and opinions of authors expressed herein do not necessarily state or reflect those of the United States Government or the University of California, and shall not be used for advertising or product endorsement purposes.

This work was performed under the auspices of the U.S. Department of Energy by University of California, Lawrence Livermore National Laboratory under Contract W7405-Eng-48. 


\section{Data Summary for the Pre Survey Interim Status Closure of the Area 514 Facility}




\section{Contents}

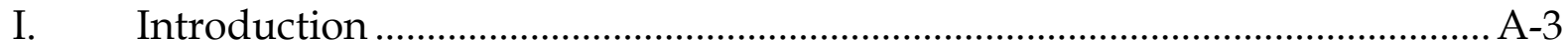

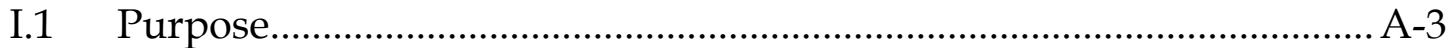

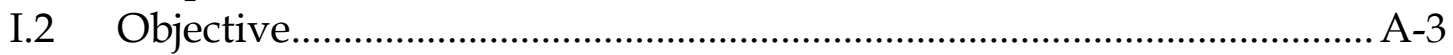

II. Scope of Work for Survey ………………..................................................... A-3

III. Sample Acquisition Description …………………..................................... A-3

IV. Sample Acquisition Location Discussion ................................................... A-7

V. Comments ................................................................................................ A-8

Figures

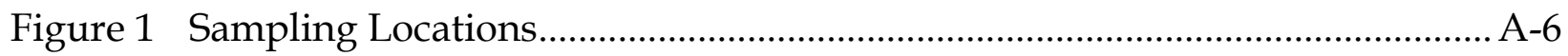

\section{Appendices}

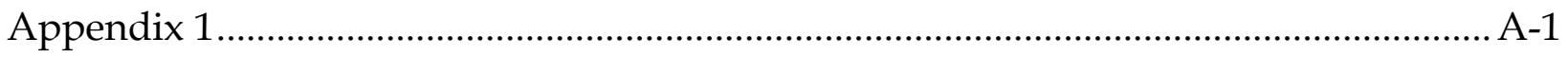




\section{Data Summary for the Pre Survey Interim Status Closure of the Area 514 Facility}

\section{Introduction}

\section{I.1 Purpose}

The purpose of this document is to summarize the data obtained from the sampling and analysis of selected locations in the Area 514 Facility.

\section{I.2 Objective}

The objective of this document is to evaluate the data in a manner that will provide guidance for the final closure document. This guidance will assist in designing a sampling and analysis plan that will be efficient, cost effective and meet the criteria for acceptance by a independent state certified engineer for completion of the closure activity.

\section{Scope of Work for Survey}

The overall scope of work was limited to the Area 514 Facility, excluding the B-513 building, the newly installed Quad tanks and the treatment tanks that are currently in use.

\section{Sample Acquisition Descriptions}

Following are acquisition descriptions of each sample location shown in Figure 1.

(S) Swipe Sample - Using a Whatman, grade 50 filter paper over one $400 \mathrm{sq} / \mathrm{cm}$ square, broken into four $100 \mathrm{sq} / \mathrm{cm}$ quadrants. Each quadrant represents one sample test (example: Total Threshold Limit Concentration Metals (TTLC), TTLC Hg, Gross Alpha/Beta, and Tritium).

(B) Bulk Sample - Chipped or scraped sample media over a given sample location to meet the minimum weight requirement per analysis (usually about 50-100 grams).

(2) denotes the collection of two separate bulk layered samples.

Site \#1 \{514-1\}(S/B)- Sump area located approx. 20 feet west of and inside the north vehicle gate. A bulk sample (COC \# 6477 item 1) of iron oxide (rust) was scraped using a putty knife on the inside of a carbon steel pipe measuring 7" in diameter. A swipe sample (COC\# 6476 item 1) was taken inside the pipe below the area that was scraped.

Site \#2 \{514-2\} (S/B)- Sump area located approx. 19.5 feet west of and inside the north vehicle gate. A swipe sample (COC\# 6476 item 2) was taken using the $400 \mathrm{sq} / \mathrm{cm}$ 
template. A bulk sample (COC\# 6477 item 2) of cured epoxy paint measuring approx. three inches in diameter was taken over the area that was swiped.

Site \#3 \{514-3 / 3A\} (S/B(2)) - 3" Gate Valve located approx. 12 feet north of the south vehicle gate. The dirt was collected as a composite bulk sample (COC\# 6477 item 3). A swipe sample (COC\# 6476 item 3 ) was taken over the same area as the dirt using the $400 \mathrm{sq} / \mathrm{cm}$ template. A bulk sample (COC\# 6477 item 4) measuring approx. three inches square was taken of the asphalt.

Site \#4 \{514-4\} (S/B) - Open asphalt area located approx. 25 feet of south vehicle gate and in center of yard. A swipe sample (COC\# 6476 item 4) was taken using the $400 \mathrm{sq} / \mathrm{cm}$ template. A bulk sample (COC\# 6477 item 5) of asphalt measuring approx. three inches square was taken over the area that was swiped.

Site \#5 \{514-5\} (S/B) - Center cell of area 514-2 Container Storage Unit in the left lower area of the berm. A swipe sample (COC\# 6476 item 5) was taken using the $400 \mathrm{sq} / \mathrm{cm}$ template. A bulk sample (COC\# 6477 item 6) of cured resin coating measuring approx. three inches in diameter was taken over the area that was swiped. A yellow colored resin was noted in this sample and identified as a flagging material used in the application of the resin coating.

Site \#6 \{514-6 / 6A\} (B(2))- Three inch culvert drain located adjacent to the reagent storage building (south). The dirt was collected as a composite bulk sample (COC\# 6477 item 7). A bulk sample (COC\# 6477 item 8 ) measuring approx. three inches square was taken of the asphalt.

Site \#7 \{514-7\} (S/B) - 514-3 Container Storage Unit in the left sump of the berm. No detectable activity above background was noted. A swipe sample (COC\# 6476 item 6) was taken using the $400 \mathrm{sq} / \mathrm{cm}$ template. A bulk sample (COC\# 6477 item 9) of cured resin coating measuring approx. three inches in diameter was taken over the area that was swiped. A yellow colored resin was noted in this sample and identified as a flagging material used in the application of the resin coating.

Site \#8 \{514-8\} (S/B) - Dorr Oliver Room adjacent to the Area 514 Waste Water Filtration Unit and Sump. The sample location was on the wall approx. three feet from the floor. A swipe sample (COC\# 6476 item 7) was taken using the $400 \mathrm{sq} / \mathrm{cm}$ template. A bulk sample (COC\# 6477 item 10) of cured resin coating measuring approx. three inches in diameter was taken over the area that was swiped.

Site \#9 \{514-9\} (S/B) - Dorr Oliver Room adjacent to the Area 514 Waste Water Filtration Unit and Sump. The sample location was on the floor. A swipe sample (COC\# 6476 item 8) was taken using the $400 \mathrm{sq} / \mathrm{cm}$ template. A bulk sample (COC\# 6478 item 1) of cured resin coating measuring approx. three inches in diameter was taken over the area that was swiped.

Site \#10 \{514-2\} (S) - Roof area for the B-514-2 Container Storage. A swipe sample (COC\# 6531 item 1) was taken using the $400 \mathrm{sq} / \mathrm{cm}$ template. 
Site \#11 \{514-TF\} (S) - Roof area for the B-514-TF Tank Farm. A swipe sample (COC\# 6531 item 2) was taken using the $400 \mathrm{sq} / \mathrm{cm}$ template.

Site \#12 \{514-A\} (S) - Roof area for the B-514-3 Container Storage. A swipe sample (COC\# 6531 item 3) was taken using the $400 \mathrm{sq} / \mathrm{cm}$ template.

Site \#13 \{514-Office\} (B) - Roof area for the B-514-Office. A bulk sample (COC\# 6531 item 4 \& 5) was taken using the $400 \mathrm{sq} / \mathrm{cm}$ template.

NOTE: A Swipe BLANK was submitted to establish background (COC\# 6476 item 9). 


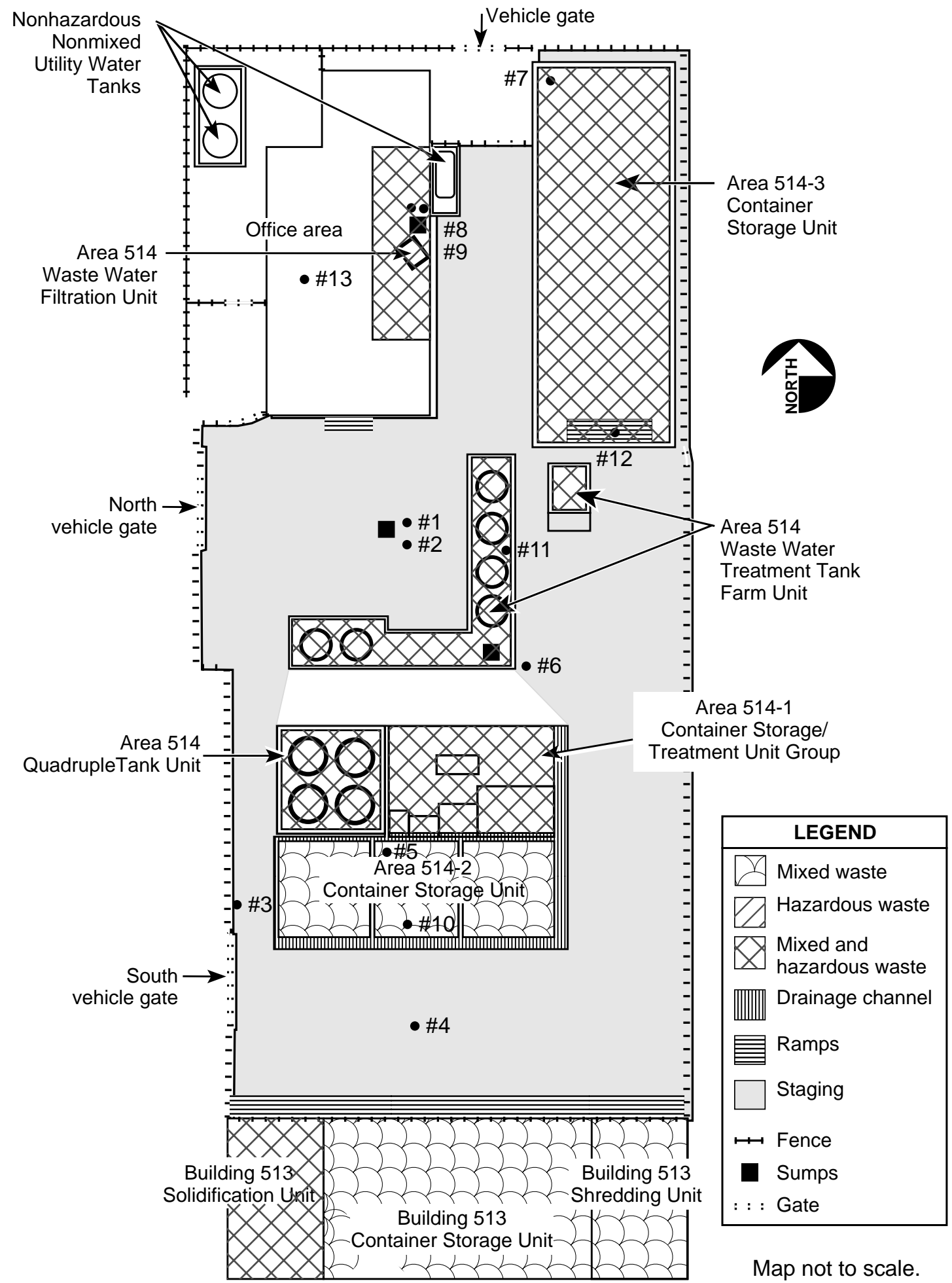

Figure 1: Sampling Locations 


\section{Sample Acquisition Location Discussion}

Following is a discussion on each sample location for each sample location shown in Figure 1.

Site \#1 \{514-1\}(S/B) - Sump area located approx. 20 feet west, inside the north vehicle gate. No activity above background was noted during the sampling of this location. Total metals and radioactivity were significantly higher than other locations. This was expected since this is an old drain trap with the possibility of accumulation higher than other areas in the facility.

Site \#2 \{514-2\} (S/B) - Sump area located approx. 19.5 feet west, inside the north vehicle gate. No activity above background was noted during the sampling of this location. Contamination levels were not significant.

Site \#3 \{514-3 / 3A\} (S/B(2) - 3" Gate Valve located approx. 12 feet north of the south vehicle gate. During the surveying of this sample location approx. 1000 CPM was detected using an E-120 w/HP-210 pancake probe. The activity was isolated to an area of built up dirt located in and around the inlet of the drain. Analytical results show that the dirt sample had no significant levels of contamination. After sample was removed, a survey by Hazards Control did not detect any activity and the area was released. The dirt sample activity matched that of natural activity in soils.

Site \#4 \{514-4\} (S/B) - Open asphalt area located approx. 25 feet of south vehicle gate and centered. No activity above background was noted during the sampling of this location. Contamination levels were not significant.

Site \#5 \{514-5\} (S/B) - Center cell of area 514-2 Container Storage Unit in the left lower area of the berm. No activity above background was noted during the sampling of this location. Contamination levels were not significant.

Site \#6 \{514-6 / 6A\} (B(2) - 3" culvert drain located adjacent to the reagent storage building (south). No activity above background was noted during the sampling of this location. Contamination levels were not significant.

Site \#7 \{514-7\} (S/B) - 514-3 Container Storage Unit in the left sump of the berm. Due to the storage of Transuranic (TRU) and MBA near the sample location, an accurate survey of the sample area could not be completed. However, after the removal of the bulk sample, a survey of the bulk media was conducted in a low background area. No detectable activity above background was noted. Contamination levels were not significant.

Site \#8 \{514-8\} (S/B) - DO Room adjacent to the Area 514 Waste Water Filtration Unit and Sump. No activity above background was noted during the sampling of this location. Contamination levels were not significant. 
Site \#9 \{514-9\} (S/B) - DO Room adjacent to the Area 514 Waste Water Filtration Unit and Sump. No activity above background was noted during the sampling of this location. Contamination levels were not significant.

Site \#10 \{514-2\} (S) - Roof area for the B-514-2 Container Storage. No activity above background was noted during the sampling of this location. A swipe sample (COC\# 6531 item 1) was taken using the $400 \mathrm{sq} / \mathrm{cm}$ template.

Site \#11 \{514-TF\} (S) - Roof area for the B-514-TF Tank Farm. No activity above background was noted during the sampling of this location. Contamination levels were not significant.

Site \#12 \{514-A\} (S) - Roof area for the B-514-3 Container Storage. No activity above background was noted during the sampling of this location. Contamination levels were not significant.

Site \#13 \{514-Office\} (B) - Combined with \#12 as a composite. Roof area for the B-514Office. No activity above background was noted during the sampling of this location. Contamination levels were not significant.

\section{Comments}

In general, contamination levels were consistently low throughout the facility. Even the TTLC values, though elevated in some locations, were at a level that can be assumed would pass a TCLP or an STLC analysis. Radioactivity levels were also low in the low $\mathrm{pCi} / \mathrm{g}$ levels and other than the iron pipe sample, 514-1 can be considered primordial or at background.

Based on the data obtained in the pre-survey the final closure activity can probably be accomplished with minimal decontamination effort and a small number of samples for verification.

Treatment tanks, equipment and ancillary parts will be sampled for release after cessation of treatment activities. Structural areas will be verified after removal of equipment. Final verification will include metals, radioactivity, solvents, and PCBs. Solvents and PCBs are not expected to be present, since treatment volumes have low specified solvent concentration limitations for all treatments. All other sampling activities will be done using methodology similar to that in the Presurvey Plan. 


\section{ANALYTICAL DATA}




\begin{tabular}{|c|c|c|c|c|c|c|c|c|c|c|c|c|c|c|c|c|c|c|c|c|}
\hline \multicolumn{21}{|c|}{ METALS TTLC } \\
\hline & & & & & & & & & & & & & & & & & & & & \\
\hline \multicolumn{21}{|l|}{ SWIPES (ug) } \\
\hline LOCATION & DESCRIPTIOI & SAMPLE \# & $\mathbf{A g}$ & As & Ba & $\mathrm{Be}$ & Cd & Co & $\mathrm{Cr}$ & $\mathbf{C u}$ & $\mathrm{Hg}$ & Mn & Mo & $\mathbf{N i}$ & $\mathbf{P b}$ & Sb $s$ & Se & TI & V & Zn \\
\hline & & & & & & & & & & & & & & & & & & & & \\
\hline $514-1$ & Iron Pipe & 45028 & 5 & $<5$ & 40 & $<0.1$ & $<0.2$ & $<0.5$ & 20 & 40 & 2 & 22 & 1 & 9 & 39 & $<2$ & $<2$ & $<4<$ & $<0.5$ & 65 \\
\hline $514-2$ & Berm & 45029 & $<1$ & $<5$ & 4 & $<0.1$ & $<0.2$ & $<0.5$ & 5 & 10 & $<0.4$ & 15 & $<0.5$ & 5 & 2 & $<2$ & $<2$ & $<4<$ & $<0.5$ & 20 \\
\hline $514-3$ & Asphalt & 45030 & $<1$ & $<5$ & 4 & $<0.1$ & $<0.2$ & $<0.5$ & 1 & 7 & 0.5 & 8 & $<0.5$ & 1 & 2 & $<2$ & $<2$ & $<4<$ & $<0.5$ & 77 \\
\hline $514-4$ & Asphalt & 45031 & $<1$ & $<5$ & 1 & $<0.1$ & $<0.2$ & $<0.5$ & $<0.5$ & 1 & $<0.4$ & 2 & $<0.5$ & $<1$ & $<2$ & $<2$ & $<2$ & $<4<$ & $<0.5$ & 21 \\
\hline $514-5$ & Berm & 45032 & $<1$ & $<5$ & 2 & $<0.1$ & $<0.2$ & 1 & 2 & 10 & $<0.4$ & 3 & $<0.5$ & $<1$ & $<2$ & $<2$ & 2 & $<4<$ & $<0.5$ & 66 \\
\hline $514-7$ & Asphalt & 45033 & $<1$ & $<5$ & 7 & $<0.1$ & $<0.2$ & $<0.5$ & 2 & 5 & $<0.4$ & 12 & $<0.5$ & 2 & 2 & $<2$ & $<2$ & $<4<$ & $<0.5$ & 35 \\
\hline $514-8$ & Wall & 45034 & $<1$ & $<5$ & 1 & $<0.1$ & $<0.2$ & $<0.5$ & $<0.5$ & 1 & 1. & $<0.2$ & $2<0.5$ & $<1$ & $<2$ & $<2$ & $<2$ & $<4<$ & $<0.5$ & 10 \\
\hline $514-9$ & Floor & 45035 & $<1$ & $<5<$ & $<0.2$ & $<0.1$ & $<0.2$ & $<0.5$ & $<0.5$ & $<1$ & $<0.4$ & $<0.2$ & $2<0.5$ & $<1$ & $<2$ & $<2$ & $<2$ & $<4<<<$ & $<0.5$ & 13 \\
\hline $514-10$ & Roof-2 & 45308 & $<1$ & $<10$ & 6 & $<0.1$ & $<0.5$ & $<0.5$ & 1 & 4 & $<0.4$ & 8 & $<0.8$ & $<2$ & 2 & $<5$ & $<5<$ & $<10$ & $<2$ & 380 \\
\hline $514-11$ & Roof-TF & 45309 & $<1$ & $<10$ & 5 & $<0.1$ & $<0.5$ & $<0.5$ & 7 & 2 & $<0.4$ & 6 & $<0.8$ & $<2$ & 2 & $<5$ & $<5<$ & $<10$ & $<2$ & 12 \\
\hline $514-12$ & Roof-A & 45310 & $<1$ & $<10$ & 5 & $<0.1$ & $<0.5$ & $<0.5$ & 1 & 2 & $<0.4$ & 6 & $<0.8$ & $<2$ & 2 & $<5$ & $<5<$ & $<10$ & $<2$ & 280 \\
\hline Blank & ** & 45313 & $<1$ & $<1 C<$ & $<0.2$ & $<0.1$ & $<0.5$ & $<0.5$ & $<0.5$ & $<1$ & $<0.4$ & $<0.2$ & $2<0.8$ & $<2$ & $<2$ & $<5$ & & $<10$ & $<2$ & $<1$ \\
\hline Blank & ** & 45036 & $<1$ & $<5<$ & $<0.2$ & $<0.1$ & $<0.2$ & $<0.5$ & $<0.5$ & $<1$ & $<0.4$ & $<0.2$ & $2<0.5$ & $<1$ & $<2$ & $<2$ & $<2$ & $6<$ & $<0.5$ & 2 \\
\hline
\end{tabular}




\begin{tabular}{|c|c|c|c|c|c|c|c|c|c|c|c|c|c|c|c|c|c|c|c|}
\hline METALS TTLC & & & & & & & & & & & & & & & & & & & \\
\hline \\
\hline BULK (mg/Kg)
\end{tabular}




\begin{tabular}{|c|c|c|c|c|c|c|c|}
\hline RADIOLOGICAL & & & & & & & \\
\hline & & & & & & & \\
\hline \multicolumn{8}{|l|}{ Survey/CPM } \\
\hline \multicolumn{8}{|l|}{ Swipe-dpm $/ 100 \mathrm{~cm}^{2}$} \\
\hline \multirow[t]{2}{*}{ LOCATION } & DESCRIPTIO & SAMPLE \# & Survey & Survey & Swipe & Swipe & Swipe \\
\hline & & & Alpha & \multicolumn{3}{|c|}{ Beta/GammaGross AlphaGross Beta } & Tritium \\
\hline $514-1$ & Iron Oxide & 45028 & BKG & BKG & 0.5 & 1.1 & 49 \\
\hline $514-2$ & Epoxy Paint & 45029 & BKG & BKG & 0 & 0 & 22 \\
\hline $514-3$ & Dirt & 45030 & BKG & BKG & 0.5 & 0 & 38 \\
\hline $514-4$ & Asphalt & 45031 & BKG & BKG & 0.5 & 0.3 & 24 \\
\hline $514-5$ & Resin Coating & 45032 & BKG & BKG & 0 & 1.9 & 28 \\
\hline $514-7$ & Resin Coating & 45033 & BKG & BKG & 0 & 1.1 & 50 \\
\hline $514-8$ & Epoxy Paint & 45034 & BKG & BKG & 0 & 1.1 & 18 \\
\hline $514-9$ & Epoxy Paint & 45035 & BKG & BKG & 0 & 1.9 & 29 \\
\hline $514-2$ & Roof & 45308 & BKG & BKG & 1.4 & 4.3 & 6 \\
\hline 514-TF & Roof & 45309 & BKG & BKG & 0.5 & 0 & 8 \\
\hline \multirow[t]{3}{*}{ 514-A } & Roof & 45310 & BKG & BKG & 0.5 & 0 & 7 \\
\hline & Blank & 45313 & BKG & BKG & 0 & 0 & 7 \\
\hline & Blank & 45036 & BKG & BKG & 0 & 1.9 & 21 \\
\hline & & & & & & & \\
\hline & & & & & & & \\
\hline & & & & & & & \\
\hline & & & & & & & \\
\hline & & & & & & & \\
\hline & & & & & & & \\
\hline & & & & & & & \\
\hline \multicolumn{8}{|c|}{ Regulatory limits for swipes are as follows; } \\
\hline \multicolumn{8}{|c|}{ Gross Alpha-20 dpm/100cm2 } \\
\hline \multicolumn{8}{|c|}{ Gross Beta-200 dpm/100cm2 } \\
\hline Tritium-1000 dpm/10 & Jcm2 & & & & & & \\
\hline
\end{tabular}




\begin{tabular}{|c|c|c|c|c|c|}
\hline \multicolumn{6}{|c|}{ RADIOLOGICAL } \\
\hline \multicolumn{6}{|l|}{ BULK (pCi/g) } \\
\hline LOCATION & DESCRIPTIO & SAMPLE \# & Gross Alpha & Gross Beta & Tritium \\
\hline $514-1$ & Iron Oxide & 45037 & 340 & 370 & 85 \\
\hline $514-2$ & Epoxy Paint & 45038 & 4.2 & 7.1 & $<\mathrm{MDC}$ \\
\hline $514-3$ & Dirt & 45039 & 15 & 26 & $<\mathrm{MDC}$ \\
\hline $514-3 A$ & Asphalt & 45040 & 4 & 4.9 & $<M D C$ \\
\hline $514-4$ & Asphalt & 45041 & $<\mathrm{MDC}$ & 2.5 & $<\mathrm{MDC}$ \\
\hline $514-5$ & Resin Coating & 45042 & $<M D C$ & $<$ MDC & $<M D C$ \\
\hline $514-6$ & Dirt & 45043 & 15 & 25 & $<M D C$ \\
\hline $514-6 \mathrm{~A}$ & Asphalt & 45044 & 3.5 & 12 & $<M D C$ \\
\hline $514-7$ & Resin Coating & 45045 & $<M D C$ & $<M D C$ & $<M D C$ \\
\hline $514-8$ & Epoxy Paint & 45046 & $<M D C$ & $<M D C$ & $<$ MDC \\
\hline $514-9$ & Epoxy Paint & 45047 & $<\mathrm{MDC}$ & $<\mathrm{MDC}$ & 23 \\
\hline
\end{tabular}




\begin{tabular}{|c|c|c|c|c|c|c|c|c|c|c|c|c|c|}
\hline \multicolumn{14}{|c|}{ ADIOLOGICAL } \\
\hline BULK & & & & & & & & & & & & & \\
\hline & & & & & & & & & & & & & \\
\hline LOCATION & & & $\mathrm{Be}-7$ & $\mathrm{~K}-40$ & $\mathrm{C} 0-60$ & Cs-137 & Ra-226 & Ra-228 & Th-228 & Am-241 & U-235 & U-238 & $\mathrm{Ag}-108 \mathrm{~m}$ \\
\hline $514-1$ & Iron Oxide & 45037 & ND & 7.7 & 1.4 & 6.9 & 0.58 & ND & 0.32 & 4.4 & 0.45 & 17 & 0.21 \\
\hline $514-2$ & Epoxy Paint & 45038 & ND & ND & 0.15 & 1.8 & ND & ND & ND & ND & ND & ND & ND \\
\hline $514-4$ & Asphalt & 45041 & ND & 6 & ND & ND & 0.031 & 0.27 & 0.34 & ND & ND & ND & ND \\
\hline $514-5$ & Resin Coating & 45042 & ND & ND & ND & ND & ND & ND & ND & ND & ND & ND & ND \\
\hline $514-6$ & Dirt & 45043 & 10 & 6.4 & ND & 0.11 & 0.3 & 0.82 & 0.81 & ND & 0.32 & 16 & ND \\
\hline $514-6 \mathrm{~A}$ & Asphalt & 45044 & 1.3 & 5.8 & ND & ND & 0.39 & 0.31 & 0.44 & ND & ND & ND & ND \\
\hline $514-7$ & Resin Coating & 45045 & ND & ND & ND & ND & ND & ND & ND & ND & ND & ND & ND \\
\hline
\end{tabular}




\begin{tabular}{|c|c|c|c|c|c|c|c|c|c|c|c|c|c|}
\hline \multicolumn{14}{|c|}{ ADIOLOGICAL } \\
\hline Swipe & & & & & & & & & & & & & \\
\hline & & & & & & & & & & & & & \\
\hline LOCATION & & & Be-7 & $\mathrm{K}-40$ & $\mathrm{C} 0-60$ & Cs-137 & Ra-226 & Ra-228 & Th-228 & Am-241 & U-235 & U-238 & $\mathrm{Ag}-108 \mathrm{~m}$ \\
\hline $514-1$ & Iron Oxide & 45028 & ND & 7.7 & 1.4 & 6.9 & 0.58 & ND & 0.32 & 4.4 & 0.45 & 17 & 0.21 \\
\hline $514-2$ & Epoxy Paint & 45029 & ND & ND & 0.15 & 1.8 & ND & ND & ND & ND & ND & ND & ND \\
\hline $514-5$ & Resin Coating & 45032 & ND & 6 & ND & ND & 0.031 & 0.27 & 0.34 & ND & ND & ND & ND \\
\hline $514-7$ & Resin Coating & 45033 & ND & ND & ND & ND & ND & ND & ND & ND & ND & ND & ND \\
\hline $514-8$ & Epoxy Paint & 45034 & 10 & 6.4 & ND & 0.11 & 0.3 & 0.82 & 0.81 & ND & 0.32 & 16 & ND \\
\hline $514-9$ & Epoxy Paint & 45035 & 1.3 & 5.8 & ND & ND & 0.39 & 0.31 & 0.44 & ND & ND & ND & ND \\
\hline $514-2$ & Roof & 45308 & ND & ND & ND & ND & ND & ND & ND & ND & ND & ND & ND \\
\hline 514-TF & Roof & 45309 & ND & ND & ND & ND & ND & ND & ND & ND & ND & ND & ND \\
\hline
\end{tabular}

